\title{
CORRECTION
}

View Article Online

View Journal I View Issue

CrossMark
\&lickfor updates
Cite this: J. Mater. Chem. A, 2017, 5 ,
1786

DOI: $10.1039 / \mathrm{cta}$ ta0011b

www.rsc.org/MaterialsA

\section{Correction: Polymer-bound antioxidants in grafted membranes for fuel cells}

\author{
Yves Buchmüller, Alexander Wokaun and Lorenz Gubler* \\ Correction for 'Polymer-bound antioxidants in grafted membranes for fuel cells' by Yves Buchmüller et al., \\ J. Mater. Chem. A, 2014, 2, 5870-5882.
}

There are errors in eqn (5) in the original article, the correct equation for the calculation of the theoretical ion exchange capacity (IEC) is:

$$
\mathrm{IEC}_{\text {theo }}=\frac{\mathrm{GL}_{\text {tot }}}{\left(M_{\text {styrene }}+\frac{M_{\text {comonomer }}}{R_{\mathrm{m}}}\right)\left(1+\mathrm{GL}_{\mathrm{tot}}\right)+\mathrm{GL}_{\mathrm{tot}} \cdot M_{\mathrm{SO}_{3}}}
$$

where $\mathrm{GL}_{\text {tot }}$ is the graft level (in mass\%) of styrene and comonomer, $M_{\text {styrene }}$ is the molar mass of styrene (104.2 $\mathrm{g}$ mol ${ }^{-1}$ ), $M_{\text {comonomer }}$ is the molar mass of the comonomer, $M_{\mathrm{SO}_{3}}$ is the molar mass of $\mathrm{SO}_{3}\left(80.1 \mathrm{~g} \mathrm{~mol}{ }^{-1}\right)$ and $R_{\mathrm{m}}$ is the molar ratio of styrene and comonomer in the graft component.

In the text of the article, the correct expression was used to calculate the degree of sulfonation of the various membranes.

There are also some errors in Table 4 of the original manuscript. The correct values for the molar fraction of styrene in the grafts, $X_{\mathrm{S}}$, are given in the third column. Columns 4 to 8 are omitted for clarity.

Table 4 (partly shown) Ex situ properties for the different radiation grafted, post-functionalized and sulfonated membranes.

\begin{tabular}{lll}
\hline ETFE- $g$-P0 & Graft level & $X_{\mathrm{S}}(\mathrm{mol} \%)$ \\
\hline S & 25 & 100 \\
S/VBC (Tyr) & 66 & $62 \pm 2$ \\
S/GMA (Tyr) & 35 & $73 \pm 2$ \\
S/GMA (Tyr) & 55 & $72 \pm 3$ \\
S/GMA (diol) & 35 & $73 \pm 2$ \\
S/GMA (diol) & 55 & $73 \pm 3$ \\
Nafion NR212 & - & -
\end{tabular}

The Royal Society of Chemistry apologises for these errors and any consequent inconvenience to authors and readers. 